Sabah A Ismail

BDS, MSc, (Asst Prof)

Shaymaa SH Hassan

BDS, MSc, (Asst Lec)

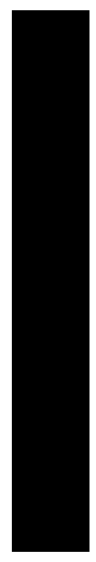

\section{Effect of Storage Time on the Degree of Conversion of Light Cured Dental Materials.}

\author{
Deptartment of Conservative Dentistry \\ College of Dentistry, University of Mosul \\ Department of Conservative Dentistry \\ College of Dentistry, University of Mosul
}

\title{
Nayif A Jado
}

Engineer

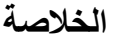

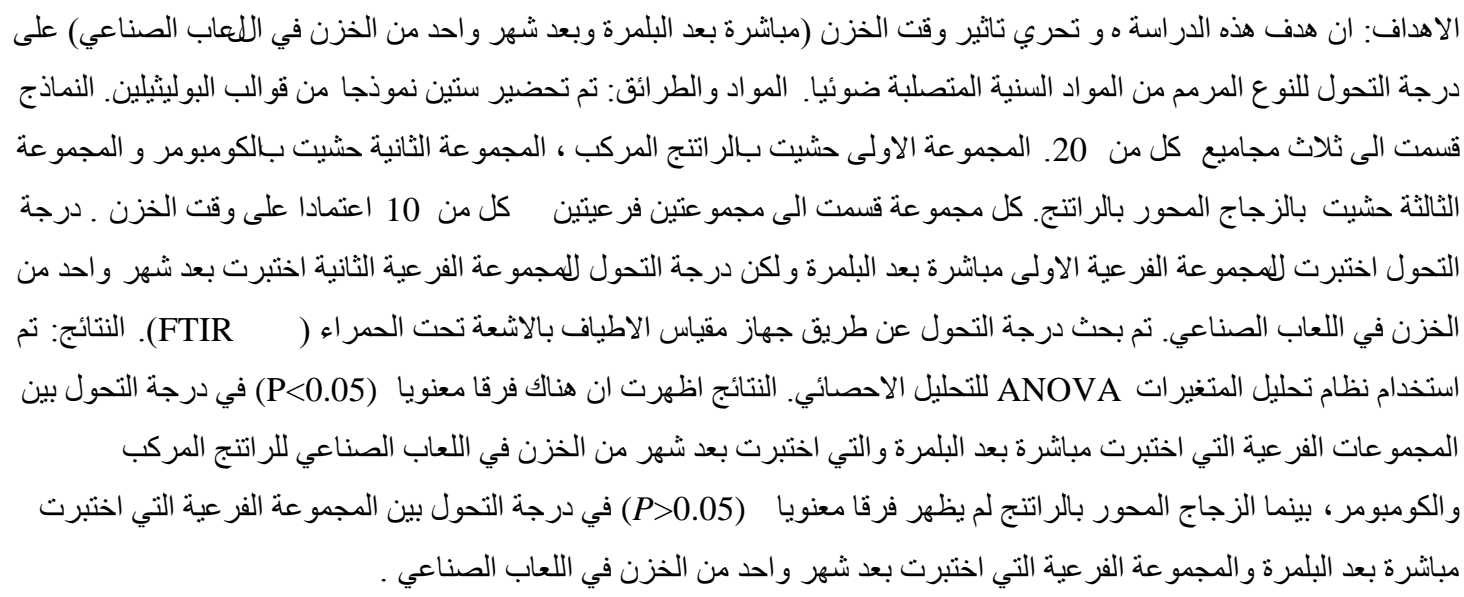

\section{ABSTRUCT}

Aims: The aim of this study was to investigate the effect of storage time (immediately after polymerization and after one month of artificial saliva storage) on the degree of conversion (DC) of restorative type of light cured dental materials. Materials and Methods: Sixty samples of polyethylene molds were prepared. The samples were divided into three groups each of 20. The first group was filled with Composite resin, second group was filled with Compomer and the third group was filled with Resin modified glass ionomer cement (RMGIC). Each group was subdivided into two subgroups; each of ten according to storage time: The DC was tested for the first subgroup immediately after polymerization, while the DC of the second subgroup was tested after one month of storage in artificial saliva. The DC was investigated by Fourier-transform infrared spectroscopy (FTIR). Results: ANOVA test was used for statistical analysis. The results showed that there was a significant difference $(p<0.05)$ in DC between the subgroups tested immediately after polymerization and the subgroups tested after one month of artificial saliva storage for Composite resin and Compomer. While RMGIC showed no significant difference $(p>0.05)$ in DC between the subgroup tested immediately after polymerization and the subgroups tested after one month of artificial saliva storage. Conclusions: One month storage time has an effect on the DC of Composite and Compomer, but it has no effect on the DC of RMGIC.

Key words: Degree of conversion, Storage time, Light cured dental materials.

Ismail SA, Hassan SH, Jado NA. Effect of Storage Time on the Degree of Conversion of Light Cured Dental Materials. Al-Rafidain Dent J. 2012; 12(2): 281-288.

Received: $3 / 2 / 2011 \quad$ Sent to Referees: $3 / 2 / 2011$

\section{INTRODUCTION}

There are two main basic types of direct aesthetic dental restorative materials: composites and glass ionomer cements ${ }^{(1)}$. There is an increasing use of polymer based composites in the restoration of cavities with the newly developed dimethacrylate monomers. A conversion of aliphatic carbon double bonds of the monomers to single bonds of polymer during polymerization is known as degree of conversion (DC). Ideally, the dental restorative resin have all of its monomer converted to polymer. However all 
dimethacrylate monomers exhibit considerable residual unsaturation in the final product. The DC ranges from 55\% to $75 \%$ under conventional irradiation conditions ${ }^{(2,3,4)}$

There are few factors which affect the DC namely, curing time, light irradiation, light curing unit and irradiation distances. It is also known that polymerization reaction of light-activated composites continues even after the end of light irradiation ${ }^{(5,6)}$. The degree of conversion affects many properties including mechanical properties, solubility, dimensional stability, color change and biocompatibility of the resin materials ${ }^{(7,8)}$. The unreacted double bonds may either be present in free monomer or as pendant groups on the network. The unreacted monomer may leach from the polymerized material and irritate the soft tissue ${ }^{(9)}$.

Conventional glass ionomer cements have been used in dental practice since their discovery. GICs are hybrid of silicate cement and the polycarboxylate cements (10)

RMGIC have been defined as glassionomer cements that are modified by the inclusion of resin monomers ${ }^{(11)}$. In these materials, visible light curing of double bonds is coupled with the polyacid matrix of conventional glass-ionomer. The composition of resin-modified glassionomer is variable but typically it consists of vinyl-modified polyalkenoic acid, a water soluble methacrylate such as hydroxyethyl methacrylate, and ionleachable glass and water ${ }^{(12)}$. The setting reaction of these materials includes a radical chain polymerization and an acid base cross-linking reaction. The polymerization can be produced by either a chemical mechanism, with a thermal activated initiator, a photochemical mechanism with a photoinitiator activated by visible light (usually in the $400-500 \mathrm{~nm}$ wavelength range), or simultaneous presence of both initiators ${ }^{(13)}$.

Since 1993, new materials known as modified polyacid composite resins or compomers have been appeared in the markets. Compomer contains polyacidmodified monomers with fluoridereleasing silicate glasses and are formulated without water (14). The compomers are hydrophopic resins by definition they contain polyacid side chains that are attached to one or more of their methacrylate monomer. They rely primarily on the light initiated free radical polymerization mechanism for curing. They are made of an acid-base reaction with a glass ionomer powder, which may also contain conventional composite glass filler. They work by absorbing water which expand the restoration over time. This absorbed water can then cause an acid-base reaction between the polyacid side chains of the resin matrix and the glass ionomer filler ${ }^{(15)}$. Initial setting is by light-activated addition polymerization and this is followed by an acid-base reaction that arises from sorption of water in situ ${ }^{(16)}$.

Among the different methods of determining the transformation of many reactions and the degree of chemical conversion, Fourier-transform infrared spectroscopy (FTIR) has proven to be a powerful technique for detecting the replacement ratio between $\mathrm{C}=\mathrm{C}$ and $\mathrm{C}-\mathrm{C}$ in methacrylate groups, as well as the $\mathrm{COOH} / \mathrm{COO}^{-}$exchange in acid-base reactions ${ }^{(17,18)}$.

The purpose of this study was to investigate the effect of storage time in the degree of conversion (DC) of light cured restorative dental materials.

\section{MATERIALS AND METHODS}

The light cured dental materials used in this study were Glasiosite Caps A2 (Compomer restorative material) (VOCO/Cuxhaven, Germany), TeEconom A2 (Composite resin restorative material) (Ivoclar Vivadent) and Vivaglass Liner (Resin modified glass ionomer cement (RMGIC) restorative material) (Ivoclar Vivadent). The light curing units used in this study was: a conventional QTH (Astralis, VIVADENT, Austria). Sample Distribution:

Sixty samples were prepared and divided into 3 groups according to materials: Composite resin (20 samples), Compomer (20 samples) and Resin modified glass ionomer (20 samples), then each group was subdivided into 2 subgroups according to storage time, half of samples (10) were tested to assess the 
degree of conversion immediately after polymerization and another half (10) was after one month storage in artificial saliva. The final number of subgroups was six subgroups.

\section{Specimen preparation}

To determine the degree of conversion (DC), samples were prepared using a polyethylene mold (Figure 1) $(5 \mathrm{~mm}$ in diameter and $1 \mathrm{~mm}$ in height) placed on glass slab.

Glasiosite Caps (Compomer) and Teeconom (Composite) were directly applied into the mold, while Vivaglass liner (RMGIC) was placed into the mold after mixing the material in a powder/liquid proportion of $1.4 \mathrm{~g} / 1.0 \mathrm{~g}$ according to manufacture instruction. Ten samples were prepared for each group. After placing the materials into the mold a celluloid strip was placed over the material and pressed with glass slide to remove any excess then glass slide was removed, to allow direct contact of the light curing tip with the prepared sample (with the exception of the thickness of celluloid strip). The specimens of Composite resin and Compomer were polymerized for 20 seconds with the curing units according to the manufacturers' instructions, and the specimens of RMGIC were polymerized for 30 seconds according to the manufacturers' instructions. The light outputs of the curing units $\left(530 \mathrm{~mW} / \mathrm{cm}^{2}\right)$ were measured before each testing procedure using a digital curing

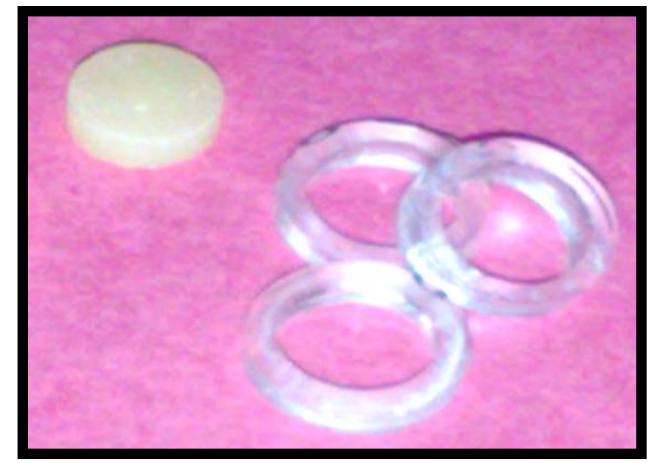

Figure(1): Polyethylene mold and sample.

radiometer (Cromatest 7041, Megaphysik, Germany).

The subgroup which was tested for degree of conversion after one month was stored in light-proof box containing an artificial saliva solution (Carboxy methyl cellulose, Sorbitol, $\mathrm{KCl}, \mathrm{NaCl}, \mathrm{MgCl}$, $\mathrm{CaCL}_{2}$, Dipotasium hydrogen phosphate and Distal water) to avoid further exposure to light irradiation.

Each specimen was individually pulverized into fine powder with a mortar and pestle (DERFLA, Germany), then the powder was mixed with potassium bromide powder at a weight percentage of 1:5. This mixture was poured into a metal mold and compressed into a disc shape by pressure device (Bruker-TENSOR, Germany) at a load of 10 tone, and the samples become ready for measurement. While the uncured samples were prepared by placement on a special cell supplied by manufacturers of FTIR, and becomes ready for measurement ${ }^{(19,20,21)}$. The spectra of the materials were obtained (Fig 2)

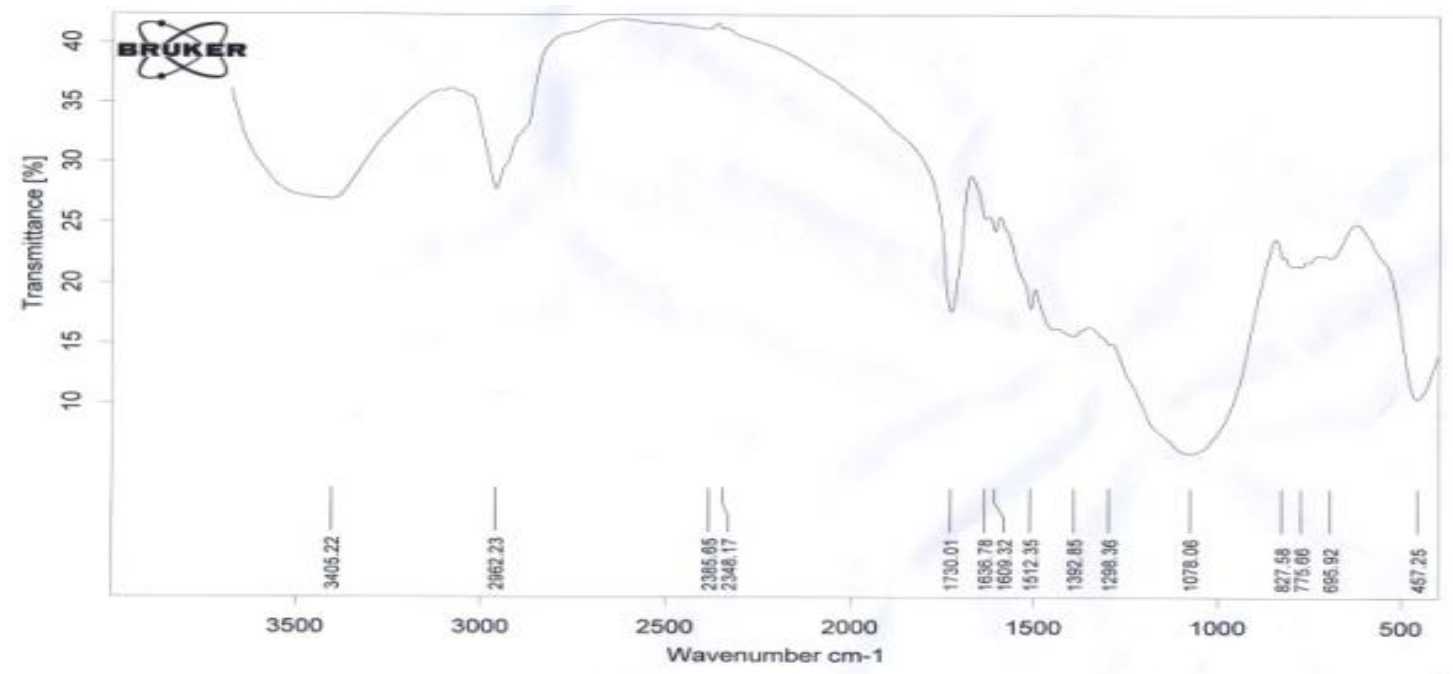

Figure (2): spectra of IR obtained 
The number of double vinyl bonds remaining in the sample exposed to irradiation is shown by the intensity of the peak at $1637 \mathrm{~cm}^{-1}$ referring to the $\mathrm{C}=\mathrm{C}$ streching of vinyl the group and have been used the study of polymerization of acrylates and methacrylates ${ }^{(9)}$. DC was calculated using the following equation:

$$
\mathrm{DC}=\left(\left(\mathrm{A}_{\mathrm{o}}-\mathrm{A}_{\mathrm{t}}\right) / \mathrm{A}_{\mathrm{o}}\right) \times 100
$$

where $A_{o}$ is the peak area of the uncured dental material, $A_{t}$ is the absorption of the peak immediately after polymerization and after the one month storage period $^{(9,22-25)}$.

\section{RESULTS}

Descriptive statistic including mean value of the degree of conversion (DC), standard deviation, standard error, minimum and maximum value of the degree of conversion and number of samples are shown in Table (1). The mean values of the degree of conversion for all groups are shown in Figure (3).

Table(1): Descriptive statistic include Mean, Standard Deviation, Standard Erorr, Minimum, Maximum, and number of groups utilized in Degree of Conversion

\begin{tabular}{|c|c|c|c|c|c|c|c|c|c|}
\hline \multirow{4}{*}{ Materials } & \multirow{4}{*}{ Groups } & \multicolumn{7}{|c|}{ Descriptive statistics } & \multirow{4}{*}{ Maximum } \\
\hline & & \multirow[t]{3}{*}{$\mathrm{N}$} & \multirow[t]{3}{*}{ Mean } & \multirow{3}{*}{$\begin{array}{c}\text { Std } \\
\text { Deviation }\end{array}$} & \multirow{3}{*}{$\begin{array}{l}\text { Std } \\
\text { Error }\end{array}$} & \multicolumn{2}{|c|}{$\begin{array}{l}95 \% \text { Confidence } \\
\text { interval for mean }\end{array}$} & \multirow[t]{3}{*}{ Minimum } & \\
\hline & & & & & & Lower & Upper & & \\
\hline & & & & & & Bound & Bound & & \\
\hline \multirow{3}{*}{$\begin{array}{l}\text { Composite } \\
\text { resin }\end{array}$} & I & 10 & 77.0640 & 3.1644 & 1.0007 & 74.8003 & 79.3277 & 72.30 & 81.00 \\
\hline & S & 10 & 85.5600 & 2.3618 & 0.7469 & 83.8705 & 87.2495 & 82.50 & 89.20 \\
\hline & Total & 20 & 81.3120 & 5.1362 & 1.1485 & 78.9082 & 83.7158 & 72.30 & 89.20 \\
\hline \multirow[t]{3}{*}{ Compomer } & I & 10 & 79.2940 & 5.0904 & 1.6097 & 75.6526 & 82.9354 & 71.07 & 84.10 \\
\hline & $\mathrm{S}$ & 10 & 70.0120 & 7.7639 & 2.4552 & 64.4580 & 75.5660 & 57.40 & 79.30 \\
\hline & Total & 20 & 74.6530 & 7.9687 & 1.7818 & 70.9236 & 78.3824 & 57.40 & 84.10 \\
\hline \multirow[t]{3}{*}{ RMGIC } & I & 10 & 95.0200 & 5.1884 & 1.6407 & 91.3084 & 98.7316 & 90.00 & 100.00 \\
\hline & $\mathrm{S}$ & 10 & 96.9900 & 4.8237 & 1.5254 & 93.5394 & 100.4406 & 90.00 & 100.00 \\
\hline & Total & 20 & 96.0050 & 4.9794 & 1.1134 & 93.6746 & 98.3354 & 90.00 & 100.00 \\
\hline
\end{tabular}

$\mathrm{I}=$ degree of conversion immediately after polymerization.

$\mathrm{S}=$ degree of conversion after one month storage.

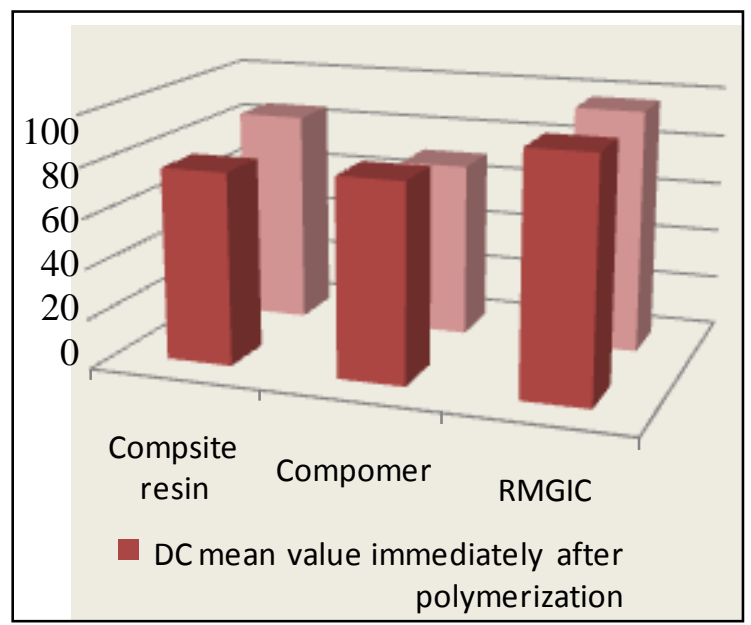

Figure (3): showing the DC mean values 
One way analysis of variance ANOVA test (Table 2) was performed for each material utilizing SPSS statistical software (SPSS, version 9.0, SPSS Inc., USA).

Table(2):One Way ANOVA Test showing the effect of storage time on the degree of conversion of Composite, Compomer and Resin modified glass ionomer.

\begin{tabular}{ccccccc}
\hline \multirow{2}{*}{ Materials } & Groups & $\begin{array}{c}\text { Sum of } \\
\text { Squares }\end{array}$ & df & $\begin{array}{c}\text { Mean } \\
\text { Square }\end{array}$ & F & Sig. \\
\cline { 3 - 7 } Composite & Between Groups & 360.910 & 1 & 360.910 & 46.295 & 0.000 \\
resin & Within Groups & 140.325 & 18 & 7.796 & & \\
& Total & 501.235 & 19 & & & \\
\hline Compomer & Between Groups & 430.778 & 1 & 430.778 & 9.996 & 0.005 \\
& Within Groups & 775.711 & 18 & 43.095 & & \\
& Total & 1206.489 & 19 & & & \\
\hline \multirow{2}{*}{ RMGIC } & Between Groups & 19.404 & 1 & 19.404 & 0.773 & 0.391 \\
& Within Groups & 451.685 & 18 & 25.094 & & \\
& Total & 471.089 & 19 & & & \\
\hline
\end{tabular}

All statistical analyses were considered significant at $P \leq 0.05$.

Analysis of variance ANOVA showed that there were significant differences between DC of Composite resin tested immediately and after one month ( $p<$ $0.05)$. The DC increased after storage.

Analysis of variance ANOVA showed that there were significant differences between DC of Compomer tested immediately and after one month $(p<$ $0.05)$. The DC value decreased after storage.

Analysis of variance ANOVA showed that there were no significant differences between DC of samples of RMGIC tested immediately and after one month $(p>$ $0.05)$.

\section{DISCUSSION}

Several techniques have been reported to determine the degree of conversion in resins. But, infrared spectroscopy has been most widely used for measuring the unreacted monomers in resin materials since Ruyter and Gyorosi ${ }^{(26)}$.

The physical and mechanical properties of resin composites are strongly influenced by the degree of conversion, defined as the percentage of reacted aliphatic $\mathrm{C}=\mathrm{C}$ bonds from the dimethacrylate monomers present in their polymeric matrices. Thus, the extent of this response plays a crucial role in the clinical performance of resin composite restorations ${ }^{(27)}$. Increasing conversion produces higher surface hardness, greater flexural strength and modulus, improved fracture toughness enhanced diametral tensile strength, and higher wear resistance $^{(28)}$. Incomplete conversion results in residual, unreacted monomer. This material and unreacted photoinitiator (and its photoreactive products) can be leached into saliva, producing allergic reactions or stimulating growth of bacteria around restoration ${ }^{(29)}$. Unreacted monomers also act as plasticizers reducing restoration mechanical strength and increasing swelling ${ }^{(30)}$.

The DC mean values observed in this study were high. This high degree of conversion may be due to thin increment of the sample $(1 \mathrm{~mm})$. Another possible reason to explain the high DC values seen in this study can be related to the heating delivered by QTH light curing unit used in this study. QTH unit generates heat (which is a major disadvantages of it), this heat produced in the 20 seconds curing procedure may raise the temperature of the restoration. Lovell et al (2003) ${ }^{(31)}$ pointed out that a greater monomer conversion would be caused by a combination of both light energy and thermal effects. In 
addition, it may be due to the adequate intensity $\left(530 \mathrm{~mW} / \mathrm{cm}^{2}\right)$ of light curing unit which used in this study.

Statistical analysis showed that the DC value of composite increased with storage for one month and this increase was statistically significant $(p<0.05)$. This is because polymerization reaction of lightactivated composites continue to proceed over a time even after the end of light irradiation and the DC showed a gradual increase after light exposure ${ }^{(23)}$. This result agreed with Gahse et al (2002) ${ }^{(32)}$ showed that after one month of water storage, a significantly increased conversion rate was observed with resin composite.

Another reason for increased DC of composite after one month storage may be due to temperature. The samples were stored for one month at constant room temperature $\left(26^{\circ} \mathrm{C} \pm 1^{\circ} \mathrm{C}\right)$, which was measured by a thermometer in the room. This temperature may enhance radical mobility resulting in additional polymerization and higher conversion. As composite temperature is raised (more than $22^{\circ} \mathrm{C}$ ), additional free volume increase giving trapped radicals increased mobility, resulting in further conversion $^{(33)}$. Radical mobility increases with temperature, and additional polymerization ensues as a result of lowerd system viscosity ${ }^{(28,30)}$.

The result shows that there were significant differences between DC values of Compomer tested immediately and after one month $(p<0.05)$. The DC value decreased after storage. Initial setting of compomer is by light activated addition reaction followed by an acid base reaction that arises from sorption of water in situ. Compomer have been reported to undergo more water absorption than composite ${ }^{(16)}$.

The decrease in DC of Compomer with time may be due to water absorption. Under wet storage, the decrease in degree of conversion of compomer may be attributed to water absorbed in the Compomer, which may have poisoned the post-polymerization $^{(24)}$. Compomer contain additional monomer that differ from those in composite which contain acidic functional groups ${ }^{(34)}$. The use of the acidic-resin monomers led to significant differences in the degree of conversion, higher acid numbers and thus higher potential for hydrogen bonding, more water may have been absorbed faster into these composites ${ }^{(24)}$.

Statistical analysis showed that there were no significant differences between DC values of samples of RMGIC tested immediately and after one month $(p>0.05)$. RMGIC appeared to be the most chemically stable. Two types of setting reactions take place in this material: acidbase reaction and light activated free radical chain polymerization ${ }^{(35)}$. In this study the RMGIC showed high DC mean value reach to 96.9 . These materials are polymerized initially more rapidly due to the addition of chemical cure initiators ${ }^{(25)}$.

\section{CONCLUSION:}

One month storage time, increased the DC of composite resin, but decreased the DC of compomer, and it has no effect on the DC of RMGIC. From clinical point, the mechanical and physical properties of composite resin restoration better than compomer restoration after one month of storage.

\section{REFERNCES}

1. Van Noort R. (1994) Introduction to dental materials. London. Mosby.

2. Ferracane JL and Greener EH. The effect of resin formulation on the degree of conversion and mechanical properties of dental restorative resin. $J$ Biomed Mater Res. 1986;20(1): 121131.

3. Eliades GC, Vougiouklakis GJ and Caputo AA. Degree of double bond conversion in light-cured composites. Dent Mater.1987;3(1):19-25.

4. Ruyter IE and Oysaed H. Composites for use in posterior teeth: composition and conversion. $J$ Biomed Mater Res.1987;21(1): 11-23.

5. Leung RL, Fan PL and Johnston WM. Post irradiation polymerization of visible light-activated composite resin. J Dent Res. 1983;62(3):363-365.

6. Tarumi H, Imazato $S$, Ehara A, Kato $S$, Ebi $\mathrm{N}$ and Ebisu S,. Post-irradiation polymerization of composites containing bis-GMA and TEGDMA. 
Dent Mater.1999;15:238-242.

7. Lohbauer U, Rahiotis C, Krämer N, Petschelt A, Eliades G. The effect of different light curing units on fatigue behavior and degree of conversion of a resin composite. Dent Mater. 2005; 21(7):608-615.

8. Silikas N, Eliades G, Watts DC. Light intensity effects on resin-composite degree of conversion and shrinkage strain. Dent Mater. 2000;16(4):292296.

9. Sideridou I, Tserki V, Papanastasiou G. Effect of chemical structure on degree of conversion in light-cured dimethacrylate-based dental resins. Biomaterials. 2002;23(8):1819-1829.

10. Wilson AD, Kent BE. New Translucent Cement for Dentistry Glass ionomer cement. Bri Dent J. 1972;132:133-135.

11. Mount GJ, Patel C, Makinson OF. Resin modified glass-ionomers: strength, cure depth and translucency. Aust Dent J. 2002;47(4):339-343.

12. Aranha AM, Giro EM, Souza PP, Hebling J, de Souza Costa CA. Effect of curing regime on the cytotoxicity of resin-modified glass-ionomer lining cements applied to an odontoblast-cell line. Dent Mater. 2006;22:864-869.

13. Micelli F, Maffezzoli A, Terzi R, Luprano VA. Characterization of the kinetic behavior of resin modified glass-ionomer cements by SC, TMA and ultrasonic wave propagation. $J$ Mater Sci Mater Med. 2001;12(2):151156.

14. Powers JM and Sakaguchi RLMechanial properties In: Graigs Restorative Dental Materials. 2006, 12 ed. Elsevier Inc. USA. Ch.4, PP.65-66.

15. Albers HFResin ionomer. In: Tooth Colored Restoratives Principles and Techniques. 2002, 9 th ed. BC Decker Inc. Ontario Canada. Ch.4, PP.64.

16. Meyer JM, Cattani-Lorento MA, Dupuis V. Compomers: between glass ionomer cements and composites. Biomaterials. 1998; 19: 529-539.

17. Matsuya S, Maeda T, Ohta M. IR and NMR. Analyses of hardening and maturation of glass-ionomer cement. $J$ Dent Res. 1996;75:1920-1927.
18. Imazato $\mathrm{S}$, McCabe JF, Tarumi $\mathrm{H}$, Ehara A, Ebisu S. Degree of conversion of composites measured by DTA and FTIR. Dent Mater. 2001;17:178-183

19. Tarle Z, Meniga A, Knzevic A, Sutalo J, Ritic M. Composite conversion and temperature rise using a conventional, plasma arc, and an experimental blue LED curing unit. $J$ Oral Rehab. 2002;29:662-667.

20. Yoon TH, Lee YK, Lim BS, and Kim $\mathrm{CW}$. Degree of polymerization of resin composites by different light sources. $J$ Oral Rehab. 2002;29:1165-1173.

21. Eva K, Viljnen, Mikael S, Pekka K Dendritic copolymer and particulate filler composites for dental applications: Degree of conversion and thermal properties. Dent Mater. 2007;23:1420-1427.

22. Ozturk N, Usumez A, Usumez S, Ozturk B. Degree of conversion and surface hardness of resin cement cured with different curing units. Quintessence Int. 2005; 36(10): 771777.

23. Pardi V, Pereira AC, Mialhe FL, Meneghim MC, Ambrosano GM. A 5year evaluation of two glass-ionomer cements used as fissure sealants. Community Dent Oral Epidemiol. 2003;31(5):386-391.

24. López-Suevos F, Dickens SH. Degree of cure and fracture properties of experimental acid resin modified composites under wet and dry conditions. Dent Mater. 2008; 24(6): 778-785.

25. Tosun G, Ozturk N, Senser $\mathrm{Y}$, Gunduz B. Effect of light curing units and storage time on the degree of conversion of fissure sealants. Rev Clin Pesq Odontol. 2009;5(2):111-119.

26. Ruyter IE, Gyorosi PP. An infrared spectroscopic study of sealants. Scand J Dent Res. 1976;84:396-400.

27. Da Silva EM, Almeida GS, Poskus LT, Guimarães JGA. Relationship between the degree of conversion, solubility and salivary sorption of a hybrid and a nanofilled resin composite: influence of the lightactivation mode. $J$ Appl. Oral 
Sci. 2008;16(2):161-166

28. Lovell LG, Lu H, Elliott JE, Stanbury JW, Bowman CN. The effect of cure rate on the mechanical properties of dental resins. ent Mater. 2001;17:504-511.

29. Reichl FX, Durner J, Hickel R, Spahl W, Kehe K, Walther U, etal. Uptake, clearance and metabolism of TEGDMA in guinea pigs. Dent Mater. 2002;18:581-589.

30. Lovell LG, Newman SM, Bowman $\mathrm{CN}$. The effect of light intensity, temperature and co-monomer composition on the polymerization behavior of dimethacrylate dental resins. J Dent Res.1999;78:1469-1476.

31. Lovell LG, Newman SM, Donaldson MM, Bowman CN. The effect of light intensity on double bond coversion and flexural strength of a model, unfilled dental resins. $J$ Dent Mater. 2003;19(6):458-465.

32. Gahse S, Lohbauer U, Frankenberger R, Petschelt A. and Kraemer N. The effect of storage time and light curing devices on conversion rate of a light curing composite. Int Assoc Dent Res.2002;58:472 (Abst).

33. Nei J, Linden LA, Rabek JF, Fouassier JP, Morlet-Savary F, etal. A Reappraisal of the polymerization kinetic of triethleneglycol dimethacrylate initiated by camphorquinione N,N-dimethyl-ptoluidine for dental purpose. Acta Polymer. 1998;49:145-161.

34. Eliades G, Vougiouklakis G, Palaghias G. Acid-base reaction and fluoride release profiles in visible light cured polyacid modified composite resin restorations. Dent Mater. 1998;1:57-63.

35. Gigo Cefaly DFM, De Mello LLC, Wang L, Lauris JRP, Dalpino PH. Effect of light curing unit on resin modified glass ionomer cements: A microhardness assessment. J Appl Oral Sci. 2009;17(3):150-154. 